An ESRC Research Group

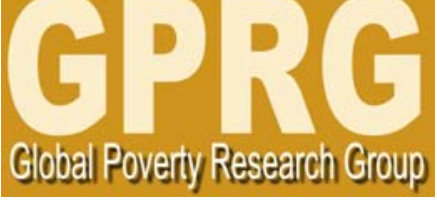

\title{
Price Transmission and Trader Entry in Domestic Commodity Markets
}

\author{
GPRG-WPS-038
}

\section{Marcel Fafchamps and Ruth Vargas Hill}

\author{
Global Poverty Research Group
}

Website: http://www.gprg.org/

The support of the Economic and Social Research Council (ESRC) is gratefully acknowledged. The work was part of the programme of the ESRC Global Poverty Research Group. 


\title{
Price Transmission and Trader Entry in Domestic Commodity
}

\author{
Markets* \\ Marcel Fafchamps \\ University of Oxford ${ }^{\dagger}$ \\ Ruth Vargas Hill \\ University of Oxford ${ }^{\ddagger}$
}

September 2005

\begin{abstract}
Using detailed data from three simultaneous surveys of producers, traders, and exporters, this paper examines the transmission of international coffee prices through the domestic value chain in Uganda. We find that producer prices fluctuations are inconsistent with constant transactions costs. We investigate two possible explanations for this finding: marketing costs that increase with price, and trader entry. We test and reject the marketing costs explanation but we find some evidence of trader entry in response to a rise in export price. Our findings suggest that small itinerant traders initiate coffee trading in response to an export price increase, probably taking advantage of farmers' ignorance of price movements.
\end{abstract}

\footnotetext{
${ }^{*}$ We are endebted to Aliziki Kaudha from the Uganda Bureau of Statistics and to Robert Waggwa Nsibirwa from the East Africa Fine Coffee Association for their assistance with an early version of this paper. We thank Panos Varangis and Pauline Tiffen for their support. Data collection was funded by the Commodity Risk Management programme of the World Bank. The support of the Economic and Social Research Council (UK) is gratefully acknowledged. This work is part of the programme of the ESRC Global Poverty Research Group.

${ }^{\dagger}$ Department of Economics, University of Oxford, Manor Road, Oxford OX1 3UQ. Email: marcel.fafchamps@economics.ox.ac.uk. Fax: +44(0)1865-281447. Tel: +44(0)1865-281446.

${ }^{\ddagger}$ Department of Economics, University of Oxford, Manor Road, Oxford OX1 3UQ. Email: ruth.hill@economics.ox.ac.uk. Fax: +44(0)1865-281447. Tel: +44(0)1865-281446.
} 


\section{Introduction}

Many agricultural commodities originating in the tropics are produced by small farmers. The price they receive for their products ultimately depend on international commodity prices, which are known to be very volatile (e.g. Deaton \& Miller 1996, Gilbert 1993, Newbery \& Stiglitz 1981). Many studies have documented the fact the producers receive a small fraction of the international price. The difference is typically explained by high transport and transactions cost and by monopsonic rents captured by private traders or public marketing boards (e.g. Akiyama, Larson, Varangis \& Baffes 1999, Coulter \& Poulton 1999, Staatz, Dione \& Dembele 1989).

Studies of the impact of liberalization on domestic agricultural markets in East and Southern Africa have highlighted that post-reform markets are generally competitive, characterized by a large number of small market participants but with few large traders and trading enterprises (e.g. Fafchamps \& Minten 1999, Fafchamps, Gabre-Madhin \& Minten 2005). The literature has also highlighted some limits to the success of liberalization, such as limited capital accumulation, nonexistent delivery mechanism for inputs and credit to farmers, inadequate storage capacity, significant inter-annual price variations, and producers' limited information on market prices (e.g. Jones 1995, Beynon, Jones \& Yao 1992, Coulter \& Golob 1992, Coulter \& Onumah 2002).

Our focus here is not so much on the gap between producer and international prices but rather on the transmission process by which changes in international prices affect prices paid to producers. Work on the integration of agricultural markets in poor countries has typically relied on co-integration analysis to test whether price series move together (e.g. Dercon 1995, Baulch 1997, Shively 1996, Badiane \& Shively 1998, Fafchamps \& Gavian 1996). Such work is normally based on commodity prices collected weekly or monthly over a long period of time in a number of physical markets. Markets located in producing areas are taken to measure the price received by producers. Little work has been done to compare the prices that producers actually receive 
to those reported by traders and exporters. This paper fills this lacuna.

Using original survey data collected simultaneously at all levels of the value chain, this paper examines the process by which changes in international commodity prices are reflected in domestic prices. The analysis is based on original data collected by the authors on all coffee exporters as well as on random representative samples of coffee traders and producers. To our knowledge, this is the first study of an African agricultural commodity using a combination of representative randomized surveys covering the entire value chain.

The data show that the price transmission mechanism in Uganda is different from what is typically assumed. We find that a rise in the international price is readily reflected in export and wholesale prices, all the way down to the first processing stage, suggesting that wholesale and export trade are reasonably competitive. But producer receive a smaller share of the international price when it rises. This finding is quite robust.

We check whether this is due to variations in marketing costs. This is not the case: the data show instead that unit marketing costs remain more or less constant in absolute terms when the international price rises. We then explore an alternative explanation, trader entry. The data indicate that a rise in the wholesale and export prices trigger entry by occasional coffee traders who tour the countryside and purchase directly from farmers. These traders tend to be much smaller than the permanent traders to whom they sell. Our interpretation of these findings is that farmers are largely ignorant of export price movements, probably because they nearly always sell directly at the farm-gate. As a result, the price at which they are willing to sell does not immediately rise in response to an increase in the export price. This makes it possible for small occasional traders to take advantage of farmers' ignorance.

The paper is organized as follows. In Section 2 we introduce the context in which the study takes place, namely Robusta coffee production in Uganda. In order to understand how 
international coffee prices affect Ugandan smallholders, it is essential to have a good grasp on how the marketing of coffee is currently organized. As we will see, Uganda coffee exports have been completely liberalized. Uganda is thus a perfect test case to study the transmission of international commodity prices through the value chain. The data used in the empirical analysis are discussed in Section 3. The empirical analysis is presented in Section 4.

\section{The context}

Much has been written on the gap between producer and export prices of agricultural commodities. In many countries the privatization of agricultural trade has been advocated as a way of ensuring that smallholders receive a fair price for their products. Yet public intervention in agricultural markets was initially justified as a way to counter the monopolistic practices of private traders. The objective of this paper is to throw some new light on this age-old debate. To this effect, it is useful to briefly describe the coffee value chain in Uganda and to recount the history of government intervention in coffee markets.

Coffee is Uganda's largest export good accounting for 26 percent of total merchandise export earnings in 2000/2001 (The Bank of Uganda 2001). It is estimated that, directly and indirectly, coffee growing provides partial employment to 5 million people in the country (Kempaka 2001). Robusta coffee accounts for nearly $90 \%$ of all Ugandan coffee, the remainder being made of Arabica. Robusta, which is native to Uganda, is predominantly grown in lowland areas of central Uganda.

Although the bimodal pattern of rainfall that Uganda receives allows for some coffee harvesting throughout the year, there are two main harvest seasons. The West of the country experiences its main harvest between May and August, with a smaller harvest occurring from October to March. The central and Eastern regions experience their main harvest from October 
to March, with a smaller harvest from May to August.

Most Ugandan coffee producers are smallholders with less than 2 hectares of cultivated land. The average size of a coffee smallholding is about 0.19 hectares (APSEC 1999). Ugandan coffee production is characterized by a very low technological level, with a low use of purchased inputs, limited use of irrigation and pesticides, and increasing incidence of coffee wilt disease. Existing Robusta trees are of a traditional variety with a potential yield of only $800 \mathrm{~kg} / \mathrm{Ha}$ of dry cherries (known locally as kiboko), as opposed to three times as much for Asian producers cit (e.g. Uganda Coffee Trade Federation 2001, APSEC 1999).

The majority of Ugandan producers sell their coffee in the form of kiboko (dry cherries). These cherries are then milled to separate the coffee beans from their husk. It is only after milling that the quality of the coffee is known. Well looked-after, healthy trees produce a ratio of $0.6 \mathrm{Kg}$ of Fair Average Quality (FAQ) coffee for $1 \mathrm{Kg}$ of kiboko while old and diseased trees can produce as little as $0.4 \mathrm{Kg} .{ }^{1}$ After the coffee has been milled and transported to Kampala, it is sorted by exporters. Broken beans, withered beans, stones and husks are discarded and the coffee beans are graded for export to coffee houses in Europe. Coffee is then called 'export grade coffee'.

Prior to market liberalization, farmers sold their harvested coffee to cooperatives or to private buyers who would mill the coffee before selling it to the Coffee Marketing Board (CMB) who would grade it before export. The price at which coffee was purchased was set annually in June. This price would remain in force for the rest of the season, irrespective of the price movements on the international coffee markets.

In the early 1990s, the coffee sector in Uganda was liberalized. Export licences were given to private export companies, and a number of policy changes were made to encourage private entry. ${ }^{2}$

\footnotetext{
${ }^{1}$ The average is around $0.54 \mathrm{Kg}$.

${ }^{2}$ The tax on coffee exports was abolished, the dual exchange rate was abandoned, pre-financing and joint
} 
The regulatory, promotional, and quality assurance roles of the CMB were given to a newly established Uganda Coffee Development Authority (UCDA). The number of private exporters initially rose rapidly before falling as a result of stiff competition and falling international prices. ${ }^{3}$

The cooperative movement in Uganda found itself weakened by the liberalization process. ${ }^{4}$ Official cooperatives had been the prime beneficiaries of government guaranteed crop finance. The 1991 removal of this financing made it possible for private coffee traders to compete with cooperatives in the procurement of unmilled coffee (Shepherd \& Farolfi 1999), leading to the gradual elimination of producer cooperatives. According to UCDA figures, producer prices increased sharply after liberalization as the price received by farmers increased to an average of about $60 \%$ of the border price, compared to $15 \%$ prior to liberalization.

By the time of the surveys, most coffee sales was taking place at the farm-gate (Fafchamps \& Hill 2005). Kiboko coffee is typically sold by farmers to small traders who tour the countryside on bicycles or motorcycles. Called "ddebe boys" after the ddebe container (a twenty kilo tin) that they use to measure the coffee, these traders act as aggregators either for bigger independent traders or for exporters and their agents. Few sales to cooperatives are reported by producers. Some producers sell directly at the market, and large-scale farmers occasionally have the coffee milled before selling it. ${ }^{5}$

ventures with foreign companies were allowed (crop financing had, until this point, been provided by the Bank of Uganda (e.g. Kawuma \& Byarugaba 1996, Ponte 2001)), and cheaper truck transportation was allowed to compete with rail.

${ }^{3}$ In 1991 export licences were given to private export companies. By 1994 the number of registered exporters had risen to 117 . The resulting stiff competition combined with falling international prices after 1996 caused many of them to exit. By the 2002/2003 season when our survey took place, there were 23 active exporters.

${ }^{4}$ For over twenty years it was responsible for some $70 \%$ of coffee procured and delivered to the CMB and $90 \%$ of the primary processing of coffee (e.g. Kawuma \& Byarugaba 1996, Nsibirwa 2001).

${ }^{5}$ Some exporters have integrated vertically by acquiring processing plants and by setting buying posts to purchase unmilled coffee directly from farmers (e.g. Ponte 2001, Nsibirwa 1999). Others use agents and subcontractors operating semi-independently. 


\section{Conceptual framework}

Armed with a better understanding of the context in which coffee production takes place in Uganda, we turn to the empirical analysis. This paper is concerned with the welfare of Ugandan farmers. The removal of government guaranteed prices has exposed the coffee sector to the vagaries of volatile international prices. Given the long time lag between tree planting and the first coffee harvest, many fear that small farmers are most affected by increased price volatility since they are unable to adjust production plans in response to price changes (Hill 2005). The objective of this paper is to provide survey-based estimates of the way in which changes in international coffee price are reflected in the prices actually paid to producers. This is accomplished by following coffee prices throughout the value chain.

Formally, let $p_{x}$ and $p_{f}$ denote the export and producer prices, respectively. Uganda being a small coffee exporter, it is reasonable to take $p_{x}$ as exogenously determined. In a competitive value chain, the difference between producer and export price reflects the actual search, transport, storage, and processing costs of traders. Let unit marketing costs be denoted $c$. For now we assume that these costs are constant. With perfect competition, a standard arbitrage argument ensures that:

$$
p_{x}-p_{f}=c
$$

which implies that the variance of $p_{f}$ is the same as the variance of $p_{x}$. Define $r_{f x}$ as the share of the export price paid to producers. We have:

$$
r_{f x} \equiv \frac{p_{f}}{p_{x}}=\frac{p_{x}-c}{p_{x}}
$$

which shows that $r_{f x}$ is an increasing function of the export price. In other words, a $10 \%$ rise in $p_{x}$ should lead to a rise of more than $10 \%$ in $p_{f}$. 
A similar result obtains with monopsony. To see this, let the domestic coffee supply be written $S\left(p_{f}\right)$ with constant price elasticity $\varepsilon$. Profit maximization by a monopsonist:

$$
\max _{p_{f}} \pi_{x}=\left(p_{x}-p_{f}-c\right) S\left(p_{f}\right)
$$

yields the usual 'mark-down' pricing rule: ${ }^{6}$

$$
p_{f}^{*}=\frac{\left(p_{x}-c\right) \varepsilon}{1+\varepsilon}
$$

It follows that in the monopsonist case:

$$
r_{f x} \equiv \frac{p_{f}^{*}}{p_{x}}=\frac{p_{x}-c}{p_{x}} \frac{\varepsilon}{1+\varepsilon}
$$

which again shows that $r_{f x}$ is an increasing function of $p_{x}$.

The same reasoning can be applied to the difference between the Uganda export price $p_{x}$ and the international price $p_{i}$. Let $x$ denote the transport price $x$ from Uganda to major export markets in Europe. Again assume that $x$ does not depend on the coffee price. If follows that the ratio of the Uganda export price on the international price $r_{x i}=p_{x} / p_{i}$ should be an increasing function of the international price $p_{i}$.

These simple observations imply that the producer price should be more volatile than the international price. Let $\kappa$ denote the monopsony power of traders and exporters (with perfect competition, $\kappa=1$; with full monopsony, $\kappa=\varepsilon /(1+\varepsilon)<1)$. Let the notation $C_{z}$ denote the

\footnotetext{
${ }^{6}$ As usual, $\varepsilon$ must be greater than 1 for an interior solution.
} 
coefficient of variation (CV) of variable $z$. We have:

$$
\begin{aligned}
p_{f} & =\left(p_{i}-c-x\right) \kappa \\
E\left(p_{f}\right) & =\kappa E\left(p_{i}\right)-\kappa(c+x)<\kappa E\left(p_{i}\right) \\
\operatorname{Var}\left(p_{f}\right) & =\kappa^{2} \operatorname{Var}\left(p_{i}\right)<\operatorname{Var}\left(p_{i}\right) \\
C_{f} & \equiv \frac{\sqrt{\operatorname{Var}\left(p_{f}\right)}}{E\left(p_{f}\right)}>\frac{\sqrt{\operatorname{Var}\left(p_{i}\right)}}{E\left(p_{i}\right)} \equiv C_{i}
\end{aligned}
$$

Equation (3.4) shows that, if trade margins are constant in absolute value, the CV of producer prices should be higher than the CV of international prices.

Thus far we have assumed that trade margins are constant regardless of $p_{i}$. We now discuss the possibility that trade margins increase when the international price rises. Many transactions costs, such as transportation, handling, and processing, depend on quantity, not on price (Gardner 1975). Consequently they should not change with $p_{i}$. But there also exist value-based transaction costs, such as the cost of working capital. Indeed, as the price rises, the need for working capital to finance purchases and storage rises proportionally. A sufficiently large increase in these costs would reduce fluctuations in $p_{f}$. It is also conceivable that a rise in $p_{i}$ increases supply and hence raises the demand for (and price of) transportation, handling, and other marketing services.

If all transactions costs are value-based, costs are proportional to $p_{i}$, i.e., we can write $c\left(p_{i}\right)=\alpha p_{i}$ and $x\left(p_{i}\right)=\beta p_{i}$. It follows that, in the competitive case:

$$
p_{f}=p_{i}(1-\alpha-\beta) \kappa
$$

implying that $C_{f}=C_{i}$ : the variation in producer prices is proportional to the variation in international prices. 
An increase in export price may fail to raise producer prices because it attracts traders to the sector. We briefly discuss two possible cases. In the first, trader entry causes a negative search externality: as more traders chase the same number of producers, it is harder for them to find coffee to buy, thereby raising the cost of market intermediation. In the second, newcomers insert themselves between producers and traders who are already present. So doing they add a new layer to the value chain and are able to capture (part of) the price increase. Both cases suppose that farmers are ignorant of movements in international prices.

Let us first illustrate the case of trader entry. To illustrate the idea in the simplest possible way, we focus on domestic marketing and ignore $x$. Imagine that producers are distributed over a large territory, each producer offering a quantity $q$ for sale. Assume that each trader purchases a quantity $q$ by incurring a search cost $c q$ proportional to the time spent searching for a seller. The number of traders is denoted $N$. To capture the idea that the presence of more traders increases search costs, let the probability of finding a seller be $1 / N$ per unit of time. The cost of one unit of time is $\theta$. The expected cost of finding $q$ is thus:

$$
c=\theta N
$$

Expected trader profit is:

$$
\pi=\left(p_{x}-p_{f}\right) q-q \theta N
$$

With free entry, traders enter up to the point where profit is zero. Setting $\pi=0$ and solving for $N$ we get:

$$
N=\frac{p_{x}-p_{f}}{\theta}
$$

which shows that, for a given $p_{f}, N$ is an increasing function of $p_{x}$.

In the case of perfect competition between traders, this simple model has an infinity of 
equilibria. For any level of $p_{f}$, entry occurs up to the point where the increase in search costs exactly matches the difference between $p_{x}$ and $p_{f}$. To see this formally, replace $p_{f}$ in equation (3.6) by its value given by equation (3.1) and let $c=\theta N$. We obtain:

$$
N=\frac{p_{x}-\left(p_{x}-\theta N\right)}{\theta}=N
$$

which shows that the number of traders - and hence $p_{f}$ - are indeterminate. This means that, by themselves, competition and free entry do not generate an upward pressure on $p_{f}$ : gains from a rise in $p_{x}$ are entirely dissipated by the negative search externality. The producer price $p_{f}$ will rise only if farmers become aware of the rise in $p_{x}$ and threaten to bypass traders by selling directly at price $p_{x}$. How quickly this will happen depends on the institutional setting and on farmers' access to information and capital.

Given that the model has multiple equilibria, let us tie down the equilibrium by imagining that the price at which farmers are willing to sell follows an adaptive process. Behind this assumption is the idea that farmers are ill informed about changes in export prices. In the context of Uganda, this is not an unreasonable assumption given that over half the farmers interviewed $(55 \%)$ reported that they did not receive price information from anyone other than the buyer of their coffee and that, as Fafchamps \& Hill (2005) have shown, most farmers (85\%) sell at the farm-gate. Only a minority of farmers travel to the market in order to sell their coffee, where they presumably acquire more up to date information about coffee prices. ${ }^{7}$ As this information gradually spreads to other farmers, the price at which farmers accept to sell coffee

\footnotetext{
${ }^{7}$ Furthermore, for several decades the coffee price was set by the government for the whole season. Coffee farmers, who on average are quite old, may not not mentally adjusted to the idea that coffee prices change dramatically from week to week.
} 
may change over time. Formally, let this adaptive process be written:

$$
p_{f t+1}-p_{f t}=\gamma\left(p_{x t+1}-p_{f t}\right)
$$

Parameter $\gamma$ captures the extent to which farmers revise their offer price based the evolution of the export price $p_{x}$ : if $\gamma=0$, no price revision takes place; if $\gamma=1, p_{f}$ instantaneously adjusts to the export price.

We further assume that trader entry and exit is rapid so that the number of traders fully adjusts to the new farm-gate price. ${ }^{8}$ Underlying this assumption is the observation that many Ugandan coffee traders also deal in other agricultural products, as is common in African agricultural trade (e.g. Fafchamps \& Minten 1999, Fafchamps, Gabre-Madhin \& Minten 2005). For them, entry and exit in coffee trade is only a matter of switching from one crop to another. Solving for the law of motion of $N$, we obtain:

$$
\begin{aligned}
N_{t+1} & =\frac{p_{x t+1}-p_{f t+1}}{\theta} \\
& =\frac{1-\gamma}{\theta}\left(p_{x t+1}-p_{f t}\right) \\
& =(1-\gamma)\left(\frac{p_{x t+1}-p_{x t}}{\theta}+N_{t}\right)
\end{aligned}
$$

where we have made use of equations (3.6) and (3.7). Equation (3.8) shows that if $\gamma=0$ an increase in the export price translates into an increase in $N$ : traders enter to take advantage of farmers' failure to fully adjust the price at which they sell. ${ }^{9}$

\footnotetext{
${ }^{8}$ It of course be possible to posit an adaptative process for entry and exist as well, in which case non-zero profits would arise in the short-run. Given that the emphasis of this paper is empirical, we ignore these complications as they are not necessary to illustrate our point.

${ }^{9}$ The cautious reader will note that if $\gamma=1, N=0$. This result obtains because we have implicitly assumed that farmers could potentially sell at the export price without incurring any transactions cost. This is obviously a simplification. Adding a constant transaction cost to the model would ensure that $N>0$. We abstract from this detail to keep our notation as simple as possible, but adding it to the model does not change our conclusions.
} 
This simple model has implications regarding the relative variation of $p_{f}$ and $p_{x}$. If $\gamma=0$ and $p_{f}$ does not adjust at all to a change in $p_{x}, N$ - and thus $c$ - increase so as to exactly dissipate the rise in $p_{x}$. As a result, $C_{f}=0<C_{x}$ : the producer price remains constant while the export price fluctuates. In contrast, if $\gamma=1$ and $p_{f}$ adjusts instantaneously, $N-$ and hence $c$ - remain constant but $p_{f}$ rises, and $C_{f}>C_{x}$ as discussed earlier. Intermediate cases obtain for intermediate values of $\gamma$. It follows that, with trader entry and perfect competition, whether $C_{f}<$ or $>C_{x}$ therefore ultimately depends on $\gamma$. If farmers remain ignorant of international price movements and new traders rapidly enter to take advantage of this ignorance, it is possible for $p_{f}$ to remain relatively unresponsive to a rise in $p_{x}$ even with perfect competition among traders.

The case in which entering traders insert themselves between producers and existing traders can be described using the same model but changing the interpretation somewhat. Imagine that coffee traders perform two marketing tasks: search (looking for coffee by touring the countryside) and assembly (consolidation of unmilled lots into truck-size shipments of milled coffee). ${ }^{10}$ Search is labor intensive while assembly is capital intensive. Assume that traders differ in factor cost ratios. Those with a high cost of labor relative to capital specialize in assembly; those with a low cost of labor relative to capital specialize in search. ${ }^{11}$

Assume that there is perfect competition in assembly and perfect information among traders, so that the coffee price net of assembly costs $a$ is simply $p_{x}-a$. The demand for assembly services depends on total traded quantity which we assume constant. It follows that the number of assembly traders is also constant; these are the permanent traders. Continue to assume that farmers are ignorant of price movements: when $p_{x}$ rises, $p_{f}$ does not. The number $N^{s}$ of search

\footnotetext{
${ }^{10}$ This is a fair characterization of the way coffee marketing works in rural Uganda.

${ }^{11}$ This is a reasonable assumption for Africa where trade attracts many unemployed young adults with little capital.
} 
traders - the ddebe boys - depends on the gap between $p_{f}$ and $p_{x}-a$. In this modified model, a rise in $p_{x}$ leads to a rise only in the number of search traders - those who deal directly with farmers and can take advantage of their ignorance about prices. We have:

$$
N_{t+1}^{s}=\frac{p_{x t+1}-a-p_{f t+1}}{\theta}
$$

With free entry, we obtain the same results are before, except that now they only apply to search traders. While the two models are formally similar, they have slightly different predictions regarding the price at which traders buy coffee. In the first model, all traders purchase at $p_{f}$ while in the second model some traders buy at $p_{f}$ while others buy at $p_{x}-a$. The two models also make different predictions regarding quantities purchased by individual traders. To see this, suppose that total supply is constant. In the first model, as $N$ rises the quantity purchased by each trader falls. In the second model, quantity traded remains the same for permanent traders but it falls for occasional traders. As we will see, these distinctions have important implications for data analysis. Having clarified the conceptual framework, we now turn to the empirical part of the paper.

\section{The data}

The data used in our analysis come primarily from survey data collected by the authors. Detailed data on exporters, traders and producers come from surveys conducted in Uganda in early $2003^{12}$. The objective of the surveys was to look at the effect of commodity price fluctuations on producers and to assess the potential for risk management schemes. Data were collected on all exporters of Robusta coffee. In addition, detailed interviews were conducted with a random

\footnotetext{
${ }^{12}$ The data were collected by a team from the Uganda Bureau of Statistics in collaboration with the Centre for the Study of African Economies at Oxford University. Funding was provided by the World Bank.
} 
sample of traders and producers in four coffee producing districts: Mukono, Luwero, Masaka and Bushenyi. These four districts combined account for about 50 percent of all Robusta coffee produced in Uganda.

\subsection{Producer Survey}

The sample of coffee producers was drawn randomly from a sampling frame constructed from a national household survey conducted in 1999/2000. This survey was used to identify coffee farmers in the four aforementioned districts. ${ }^{13}$ Randomly selected coffee producers were revisited in early 2003 and were asked many of the original household survey questions in addition to detailed questions on recent coffee sales. As the period between the baseline and the follow up survey was relatively short, there was little attrition resulting from death or migration. Most households were still in existence within the village and it was relatively easy to trace them. ${ }^{14}$

\subsection{Trader Survey}

A considerable degree of heterogeneity exists among domestic coffee traders in Uganda. During field testing of the trader questionnaire, two broad classes of traders clearly emerged: ddebe boys, that is, small itinerant traders who operate largely by bicycle, do not possess a store front, and buy directly from farmers to sell to large traders; and large traders who own a store or a mill, buy from small traders, and sell to exporters in Kampala.

Greater heterogeneity exists among the large traders than among small traders. The latter

\footnotetext{
${ }^{13}$ A stratified two-stage sampling design was used in the $1999 / 2000$ survey. The country was divided into enumeration areas, typically the LC1 (local council level one - essentially a village), which constituted the first stage sampling unit. The second stage sampling unit was the household. Ten households were selected from each enumeration area randomly selected at the first stage. Stratification took place at both sampling stages - all enumeration areas were stratified into urban, other urban, and rural, and households within the rural areas were further stratified into small scale farmers, large scale farmers and non-farming households.

${ }^{14}$ Some farmers identified as coffee producers on the basis of their response to the $1999 / 2000$ survey were no longer farming coffee. In these cases, the interview was nevertheless conducted but only the relevant sections of the questionnaire were completed. These respondents are not used in the analysis presented here.
} 
tend to all operate in a similar way: they purchase coffee with the small working capital they have, they sell it immediately to a larger trader, and then they buy coffee again. For this reason, it was decided to stratify the trader sample on the basis of these two types: ddebe boys and those who own a store or a mill. This stratification also corresponds to two different roles in the value chain.

The trader sampling frame was constructed as follows. In each of the four survey districts a list of large traders was constructed a few days prior to interviewing with the aid of a local guide knowledgeable of the coffee industry of a region. Exporters who had buying centers were not included to avoid duplication as these are accounted for in the exporter questionnaire. Traders were then randomly selected from this list.

Given the difficulty of locating ddebe boys - and the impossibility of conducting a listing exercise - it was decided to interview them at their point of sale, that is, when they visit large traders. The ddebe boys were thus randomly selected among small traders delivering coffee to an interviewed large trader.

A sample of just over 100 traders was randomly selected in the four selected coffee growing districts, divided equally between large and small traders. As there are many more small traders than big traders, the 50:50 stratification means that large traders are oversampled. This is done on purpose to account for their greater heterogeneity.

The survey asked questions on the structure of the respondents' trading business, their operating costs, their access to information and trading networks, and their financial and credit resources. Much of the data used here come from detailed questions on the quantities and prices in sales and purchases occurring between January to December 2002. 


\subsection{Exporter Survey}

All coffee exporters in Uganda have to be registered with UCDA. ${ }^{15}$ We interviewed all registered exporters of Robusta coffee. The survey is similar in content to the trader survey. As for traders, much of the information used in this paper comes from detailed questions on the quantities and prices of purchases and sales from January to December 2002. The exporters were the hardest group to elicit a response from, but eventually questionnaires were completed for twenty of the twenty three exporters. Three refused to cooperate. ${ }^{16}$

\section{Empirical analysis}

Having clarified how the surveys were conducted, we now turn to the transmission of international coffee prices through the domestic value chain. We proceed in two steps. We first examine the evolution of coffee prices over time, drawing from the surveys as well as from secondary data. We find that producer prices do not perfectly track export prices. We then investigate possible explanations for this failure.

\subsection{The evolution of prices over time}

We begin by documenting the extreme volatility of international and domestic coffee prices over time. Figure (5.1) presents the evolution of the price for Robusta coffee over the last decade as indicated by secondary data. The top line represents the ICO price on the London commodity

\footnotetext{
${ }^{15}$ It is believed that small quantities of Robusta coffee are exported by unregistered exporters towards neighboring countries (Sudan) for domestic consumption. It is also thought that some Robusta coffee crosses the border from Tanzania and DR Congo to be exported by Uganda. These informal border movements are ignored here as they represent a very small proportion of exports.

${ }^{16}$ Non-response occurred principally among local exporters in financial difficulties. We suspect that their reluctance to respond to interviews is related to their difficult relationship with banks and creditors. Given their financial situation, non-respondents are unlikely to have played a significative role in the price transmission mechanism. Their absence from the sample should therefore not bias our results.
} 


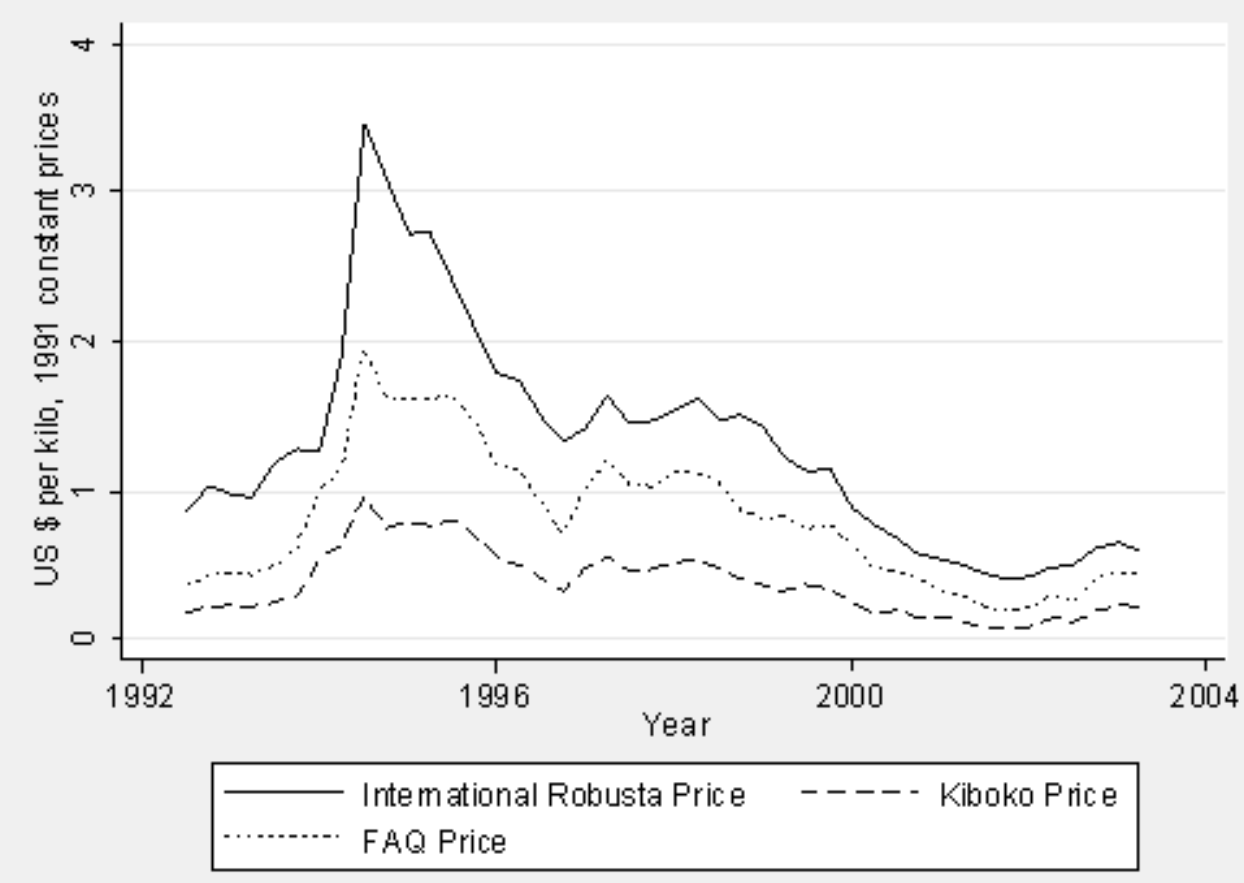

Figure 5.1: International and domestic coffee price movement, 1992 - 2003

exchange, which stands for $p_{i}$ in our model. ${ }^{17}$ All prices are in constant 1991 US \$. Over the recent past, $p_{i}$ has gone through massive fluctuations. For instance, during the last decade, it rose from around US $\$ 1$ per $\mathrm{Kg}$ in late 1992 to US $\$ 3.5$ in 1994 . It then fell below US $\$ 1.5$ by 1996 before falling further to US $\$ 0.5$ by early 2001. Fluctuations of a similar - if not larger - order of magnitude were observed in the 1980s.

Figure (5.1) also presents the evolution of Ugandan prices for kiboko (unmilled) and FAQ (milled) coffee, as reported by the Ugandan Coffee Development Authority (UCDA). To facilitate comparison with the international price, Ugandan prices have been converted to 1991 US\$. Since most producers sell their coffee unmilled (Fafchamps \& Hill 2005), we expect the farm-gate coffee price $p_{f}$ to be similar to the kiboko price. We see that over the last decade, milled and unmilled

\footnotetext{
${ }^{17}$ International coffee price data comes from the International Coffee Organization and the monthly average of indicator prices is used.
} 
coffee prices have largely followed international price movements, an outcome of the liberalization of coffee marketing in Uganda. ${ }^{18}$ It is clear from Figure (5.1) that $p_{f}$ fluctuated widely after liberalization, from a high of US\$1.12 in August 1994 to a low of US\$0.09 per Kg in September 2001. The question is: did $p_{f}$ fluctuate more than $p_{i}$ ?

In the conceptual section we have seen that, with perfect competition $(\kappa=1)$ and constant marketing costs/no entry, $\operatorname{Var}\left(p_{f}\right)=\operatorname{Var}\left(p_{i}\right)$. This is not what we find in the data. The variance of the farm-gate price $p_{f}$ is 0.05 , much below the variance of the international price which is 0.52. Testing for the equality of the variances using a variance ratio F-test, we easily reject the null hypothesis that the variances are equal against the alternative that $\operatorname{Var}\left(p_{f}\right)<\operatorname{Var}\left(p_{i}\right)$ (the $F$-statistic $F_{(35,37)}=0.101$ is significant at the $1 \%$ level). The data therefore reject the joint hypothesis of perfect competition and constant marketing costs/no entry.

In our conceptual framework, we showed that $\operatorname{Var}\left(p_{f}\right)<\operatorname{Var}\left(p_{i}\right)$ can arise because of imperfect competition. It is therefore possible that marketing costs are constant but competition is imperfect. ${ }^{19}$ We can investigate this possibility by examining how $r_{f i}$ evolves over time. In the conceptual section we have seen that if transaction costs $c$ remain constant over time, the share $r_{f i}$ of the international price received by producers should increase when $p_{i}$ rises, even in the presence of imperfect competition. A simple glance at the Figure reveals that this is not the case: if anything, the difference between $p_{i}$ and $p_{f}$ increases - and $r_{f i}$ falls - when $p_{i}$ rises.

To investigate this formally, we test whether $C_{f}>C_{i}$. Using the data presented in Figure (5.1), we find that, as predicted by the constant $c$ model, $C_{f}=0.62>C_{i}=0.57$. The difference, however, is not significant: as is clear from comparing the confidence intervals for $C_{f}$ and $C_{i}$

\footnotetext{
${ }^{18}$ Using UCDA's data on the farm-gate price of coffee since 1992 and data from (Henstridge 1997) on the farmgate price of coffee before 1992, we computed the coefficient of variation of $C_{f}$ before and after liberalisation. We find that $C_{f}$ increased from 0.38 to 0.63 after liberalisation. This rise occurred even though, over the same period, $C_{i}$ fell.

${ }^{19}$ If imperfect competition were responsible for the gap between $\operatorname{Var}\left(p_{f}\right)$ and $\operatorname{Var}\left(p_{i}\right)$, then the implied $\kappa$ would be 0.31 . This corresponds to an exporter-specific supply elasticity of 0.44 . As we will see, however, imperfect competition with constant transactions costs is not supported by the data.
} 


\begin{tabular}{lcccc}
\hline Confidence & \multicolumn{2}{c}{$C_{f}$} & \multicolumn{2}{c}{$C_{i}$} \\
Intervals & Upper & Lower & Upper & Lower \\
\hline $\mathbf{9 9} \%$ & 0.44 & 1.05 & 0.42 & 0.93 \\
$\mathbf{9 5} \%$ & 0.48 & 0.91 & 0.45 & 0.81 \\
$\mathbf{9 0} \%$ & 0.50 & 0.85 & 0.46 & 0.76 \\
\hline
\end{tabular}

Table 5.1: Confidence internals for coefficients of variation of farm-gate and international price displayed in table (5.1), the null hypothesis that $C_{f}$ and $C_{i}$ are equal cannot be rejected at any reasonable level of confidence. It appears therefore that the level of coffee price volatility is lower than what would result from constant transaction costs in the domestic marketing of coffee.

One possible explanation for these results is that UCDA prices are misleading and that Uganda producer prices are much more variable than is acknowledged in the published data. This would arise, for instance, if kiboko prices reported by UCDA were not in fact obtained from actual field observation, as claimed, but were constructed from export prices using a simple proportionality rule. ${ }^{20}$ This would explain why $p_{f}$ and $p_{i}$ appear roughly proportional over the whole period covered by Figure (5.1).

To resolve this issue, we turn to the survey data we have collected. Our data cover a much shorter period than the UCDA data - 2002 and early 2003. Producer prices are also not available for early 2002 because a shorter recall period was used in the producer survey to limit recall bias. These drawback are nevertheless compensated by the fact that, since we collected data at the level of producers, traders, and exporters using a randomized sampling method, we know that our data are reliable.

Price information from the surveys is summarized in Figure (5.2), together with the London Robusta price during the same period. Let us first look at the London ICO price $p_{i}$ and how it relates to the price at which exporters report buying Ugandan Robusta, which we denote $p_{b}$. We first note a large gap between $p_{i}$ and $p_{b}$ : on average over the period studied, $p_{b}$ amounts to $54 \%$

\footnotetext{
${ }^{20}$ Perhaps calibrated on very infrequent observation of actual kiboko prices.
} 


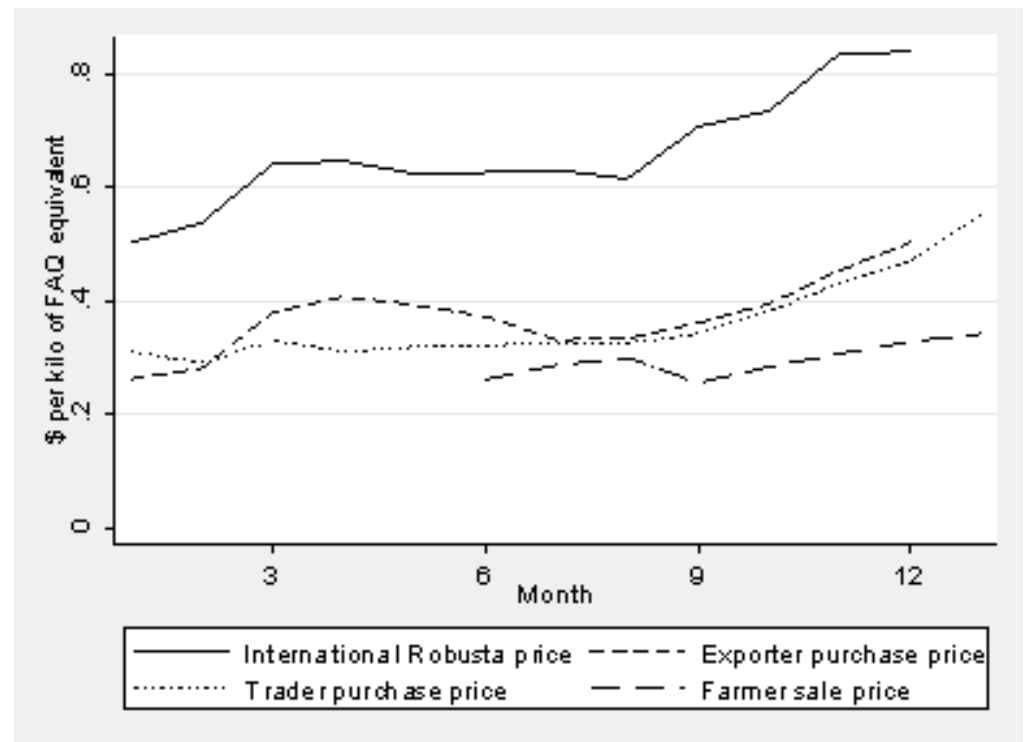

Figure 5.2: International, exporter, trader and producer prices for 2002 (US $\$$ per kilo of FAQ equivalent)

of $p_{i}$. Median exporter costs prior to shipping (for bagging, transport, grading, tax, financing etc.) are reported in the survey to be 5 cents per kilo, which is equivalent to $9 \%$ of the London price over the period studied. This leaves a difference of some $46 \%$ on average between $p_{i}$ and $p_{b}$. It would be interesting to investigate whether this difference corresponds to actual transactions costs $x$ or whether it includes a market power component as well, by analogy with equation (3.3). Unfortunately we have no information regarding shipping costs between Kampala and foreign buyers and cannot pursue this further. ${ }^{21}$

Over time, Figure (5.2) shows a gradual increase in $p_{i}$ and $p_{b}$ over the studied period, with a slight acceleration in late 2002 . We see that $p_{b}$ tracks $p_{i}$, although not perfectly. For instance,

\footnotetext{
${ }^{21}$ The majority of coffee exports from Uganda are made free-on-truck (FOT) Kampala but we were unable to elicit information about prices received by surveyed exporters. (Since some of them are controlled by multinationals, such information may not have been useful since they could easily disguise profits through under-invoicing.) Nevertheless, the general feeling in Kampala is that there is ample competition among Ugandan exporters themselves - several have gone bankrupt - so it is unlikely that exporters as a group were capable of extracting large rents during the period of inquiry. Without further information, we cannot say that this is also the case for transport through Kenya and for shipping services in Mombasa. It is conceivable that part of the price difference reflects bribes and other illicit payments paid by transporters and custom clearing agents in Uganda and Kenya. This issue deserves further investigation.
} 
the sharp rise in $p_{i}$ in September is not immediately matched by a similar increase in $p_{b}$. This is probably due to the fact that most exporters operate on 30 to 60 day contracts and are unable to reflect a rise in $p_{i}$ immediately in their purchase price.

Figure (5.2) also shows that the difference between exporter and trader purchase prices remained more or less constant over the latter half of the year, but was higher during the main harvest period in the west of the country from April to June. This may be due to congestion in transport services or to the greater distance from the main harvest region to Kampala. Indeed median transport costs were on average $30 \%$ higher for traders in the western region of Bushenyi. ${ }^{22}$ Otherwise, we find that price increases passed on by exporters are immediately reflected in the traders' purchase price. This is not surprising given that coffee traders rotate their working capital very quickly.

The lower part of the graph in Figure (5.2) shows the price actually received by producers. We see that the sale prices reported by farmers are everywhere less than the purchase prices reported by traders. In addition, although we observe a slight increase in the latter part of 2002 and early 2003, this increase is far from proportional to the increase in traders' purchase price. Our survey data thus confirms earlier findings from the UCDA data, implying that transactions costs are not constant.

Before we turn to an examination of these transactions costs, however, we need to verify that our findings do not result from a failure to recognize important time-varying determinants of coffee prices in Uganda. We begin by noting that the trader purchase price shown in figure (5.2) represents the average price over all traders. Not all traders buy directly from producers, however. Many buy from millers or smaller traders, presumably at a higher price to cover the

\footnotetext{
${ }^{22}$ For farmers that buy FAQ and sell kiboko, milling costs are also a large share of varaible costs, averaging about 1.3 cents per kilo of FAQ. Other variable costs farmers face are bagging (on average 0.2 cents per kilo), comission fees for those who use a buying agent or a broker (on average half a cent per kilo), and taxes (on average half a cent per kilo). Total variable costs come to about 3 cents per kilo (including a 0.1 cent per kilo financing cost).
} 
handling and travel costs of these intermediaries. To correct for this, we separate trader prices into prices paid for milled (FAQ) coffee, which traders typically buy from millers and other traders, and prices for unmilled (kiboko) coffee, which is the form in which most farmers sell their coffee.

The average trader price also does not control for seasonal changes in the geographical composition of reported prices. As we have seen in Section 2, some coffee growing areas in Uganda have their main season in May to August while others have their main season in November to January. To the extent that these regions are located at different distances from Kampala, the price at which traders purchase coffee may differ as a result of differential transport costs.

To control for these various factors, we reestimate average monthly prices using regression analysis. To make milled and unmilled coffee prices comparable, a coffee price in FAQ equivalent is calculated assuming an average of $0.54 \mathrm{Kg}$ of FAQ for one $\mathrm{Kg}$ of dried kiboko and an average of $0.3 \mathrm{Kg}$ of FAQ for one $\mathrm{Kg}$ of wet kiboko. This price is then regressed on monthly dummies for each type of coffee bought - kiboko and FAQ. The corrected purchase prices for FAQ and kiboko are the coefficients of the monthly dummies. To correct for differing transport costs to Kampala and the resulting effect of seasonal changes in the geographic composition of supply, we include a seasonal dummy. A weighted regression technique is used, weighting each observation by the quantity of FAQ equivalent coffee it represents. This is done so that the reported monthly average remains representative, given the likely correlation between transaction size and purchase price.

Estimated coefficients are reported in Table (5.2). They confirm the pattern apparent in Figure (5.2), namely a sustained price increase starting in October-November 2002, both for FAQ and kiboko coffee. The price increase, however, appears much more pronounced for milled than unmilled coffee: at the beginning of the period, the two prices are very close to each other, but by the end of the survey period the FAQ price is significantly larger than the kiboko price. 


\begin{tabular}{lcccccc}
\hline \hline & \multicolumn{2}{c}{ All traders } & \multicolumn{2}{c}{ Traders in central region } & \multicolumn{2}{c}{ Traders in western region } \\
Traders buying: & FAQ & Kiboko & FAQ & Kiboko & FAQ & Kiboko \\
\hline January 2002 & $0.312(0.025)$ & $0.292(0.031)$ & $0.287(0.018)$ & $0.296(0.045)$ & $0.340(0.051)$ & $0.313(0.024)$ \\
February & $0.291(0.014)$ & $0.284(0.022)$ & $0.300(0.015)$ & $0.326(0.046)$ & $0.275(0.022)$ & $0.293(0.001)$ \\
March & $0.334(0.016)$ & $0.281(0.023)$ & $0.375(0.028)$ & $0.230(0.023)$ & $0.316(0.005)$ & $0.318(0.015)$ \\
April & $0.318(0.010)$ & $0.237(0.021)$ & $0.318(0.011)$ & $0.329(0.032)$ & $0.315(0.009)$ & $0.255(0.004)$ \\
May & $0.321(0.016)$ & $0.291(0.042)$ & $0.333(0.030)$ & $0.306(0.014)$ & $0.315(0.014)$ & $0.319(0.040)$ \\
June & $0.330(0.014)$ & $0.243(0.024)$ & $0.338(0.033)$ & $0.302(0.022)$ & $0.325(0.009)$ & $0.271(0.016)$ \\
July & $0.334(0.012)$ & $0.256(0.021)$ & $0.355(0.015)$ & $0.273(0.030)$ & $0.325(0.009)$ & $0.284(0.011)$ \\
August & $0.330(0.016)$ & $0.272(0.021)$ & $0.386(0.011)$ & $0.262(0.043)$ & $0.311(0.011)$ & $0.301(0.010)$ \\
September & $0.348(0.026)$ & $0.291(0.026)$ & $0.342(0.033)$ & $0.243(0.019)$ & $0.347(0.031)$ & $0.335(0.026)$ \\
October & $0.388(0.023)$ & $0.318(0.027)$ & $0.369(0.022)$ & $0.280(0.013)$ & $0.400(0.035)$ & $0.371(0.037)$ \\
November & $0.438(0.021)$ & $0.375(0.028)$ & $0.423(0.021)$ & $0.346(0.016)$ & $0.466(0.042)$ & $0.441(0.052)$ \\
December & $0.478(0.019)$ & $0.407(0.019)$ & $0.470(0.021)$ & $0.429(0.011)$ & $0.498(0.043)$ & $0.401(0.053)$ \\
January 2003 & $0.577(0.012)$ & $0.444(0.018)$ & $0.560(0.012)$ & $0.479(0.013)$ & $0.602(0.011)$ & $0.442(0.030)$ \\
Western region & $-0.003(0.012)$ & $0.028(0.019)$ & & & & 150 \\
\hline No. of obs. & 341 & 389 & 185 & 191 & 0.536 & 198 \\
R-squared & 0.5151 & 0.4323 & 0.5097 & 0.5776 & 0.5362 & 0.4090 \\
\hline \hline
\end{tabular}

Table 5.2: Results from regression on trader purchasing prices (All month dummies are significant at 0.99$)$

To check for robustness, we estimate the regressions separately for the two main coffee producing areas covered in the survey, namely the Central region and the Western region. The purpose of this exercise is again to ensure that our results are not driven by a change in the geographical composition of supply. Results are shown in columns 3 to 6 . They confirm that coffee prices paid by traders started to rise in October-November 2002, but much more so for FAQ than kiboko.

A similar correction is needed for the price reported by producers. The producer price that was presented in Figure (5.2) is an average over all producers. Producer prices may vary with the seasonal location of the farmer. Producer prices may also vary depending on whether farmers sell at the farm-gate or travel to the nearest market to sell their coffee. In the latter case, they obtain a slightly higher price, the difference between the two reflecting the travel and search costs for itinerant traders who buy directly from farmers (Fafchamps \& Hill 2005). The type of coffee sold may also affect the price. The majority of farmers sell their coffee dried but unmilled. However some farmers do not dry their coffee before selling it, while a few mill their coffee before 
selling it.

To correct for these effects and their possible variation over time, we regress the price received by producers on month dummies, a geographical dummy, a farm-gate sale dummy, and type of coffee sold dummy. Results are presented in Table (5.3). In column 1 the changing geographic composition of prices is controlled for by including a season-location dummy. In columns 2 and 3 results are reported separately for the Central and Western regions. A weighted regression technique is used, weighting each observation by the quantity of FAQ equivalent coffee that it represents.

Regression results show that producer prices vary systematically across regions and that, in general, farmers increase the price they receive for their coffee by adding drying, transportation and milling. On average farmers receive a premium of a little over a 3 cent per kilo for selling milled coffee. Milling costs were reported uniformly as 1.3 cents per kilo of FAQ in all regions, which suggests a net return to milling for farmers. This is perhaps indicative of the high degree of uncertainty about the quality of unmilled coffee at the time of sale. Farmers also receive on average 5 cents less per Kg. for selling coffee wet. Selling wet coffee jeopardizes the quality of the coffee and also requires the trader to dry the coffee (for one or two weeks) before he sells it. Farmers typically sell wet coffee as a means of getting cash quickly: $96 \%$ of survey respondents who sold coffee wet said they did so because they needed money urgently. The lower price received may thus reflect the opportunity cost of instant liquidity. Farmers receive, on average, a 2 cent premium per Kg. for selling at the market, but the difference is not significant. ${ }^{23}$

Monthly dummies from Table (5.3) estimate monthly producer prices after correcting for all the other effects listed earlier. Corrected trader and producer prices for the most common form

\footnotetext{
${ }^{23}$ As discussed in Fafchamps \& Hill (2005), the cost of selling at the market varies across farmers depending on their distance from the market, quantity sold and costs of transport. For this reason it is difficult to determine the net return to selling at the market.
} 


\begin{tabular}{|c|c|c|c|}
\hline & \multicolumn{3}{|c|}{ Producer Price } \\
\hline & Pooled & Central Region & Western Region \\
\hline June & $0.244(0.020)$ & $0.110(0.026)$ & $0.223(0.024)$ \\
\hline July & $0.283(0.023)$ & $0.150(0.035)$ & $0.259(0.027)$ \\
\hline August & $0.270(0.021)$ & $0.229(0.032)$ & $0.243(0.025)$ \\
\hline September & $0.231(0.020)$ & $0.175(0.026)$ & $0.205(0.024)$ \\
\hline October & $0.255(0.021)$ & $0.162(0.025)$ & $0.254(0.024)$ \\
\hline November & $0.280(0.020)$ & $0.244(0.019)$ & $0.215(0.021)$ \\
\hline December & $0.287(0.022)$ & $0.241(0.020)$ & $0.242(0.033)$ \\
\hline January 2003 & $0.292(0.049)$ & $0.242(0.051)$ & $0.249(0.029)$ \\
\hline Dummy for selling at the market & $0.018(0.014)$ & $0.029\left(0.019^{\prime}\right)$ & $0.011(0.017)$ \\
\hline Dummy for drying kiboko & $0.051(0.019 * * *)$ & $0.101\left(0.019^{* * *}\right)$ & $0.032(0.024)$ \\
\hline Dummy for selling FAQ & $0.085\left(0.028^{* * *}\right)$ & $0.130\left(0.037^{* * *}\right)$ & $0.069\left(0.033^{* *}\right)$ \\
\hline Dummy for western region & $-0.046\left(0.011^{* * *}\right)$ & & \\
\hline Number of observations & 457 & 231 & 226 \\
\hline R-squared & 0.2963 & 0.2702 & 0.2040 \\
\hline
\end{tabular}

Table 5.3: Results for regression on producer price $\left(* * *\right.$ denotes significant at $0.99,{ }^{* *}$ significant at 0.95, ' significant at .85 , all month dummies are significant at 0.99 )

of sale - FAQ purchase price for traders and farm-gate kiboko price for farmers - are presented in Figure (5.3). ${ }^{24}$ The top half of the Figure reports estimates based pooled regression results, the bottom half is based on separate regressions for the Central and Western regions.

From the Figure we see that the movements of the trader prices are similar across the two regions. Corrected prices show a growing divergence towards the end of the year between prices reported by traders and farmers. To test whether this observed difference is statistically significant, we look at the standard error associated with the coefficients of monthly dummies. Figure (5.3) reports the confidence interval for monthly dummy from Tables (5.2) and (5.3). We find that, in the Central region, producer prices are statistically lower than trader prices in December 2002 and January 2003. In the Western region, the price reported by producers is significantly lower than the trader price for most months after the end of the main harvest season in August. These results confirm earlier findings obtained from the UCDA data: the share of the international coffee price that farmers receive tends to fall as the price rises.

\footnotetext{
${ }^{24}$ The FAQ purchase price shown in the graph is the estimated FAQ price less the 1.3 cents per kilo milling costs.
} 

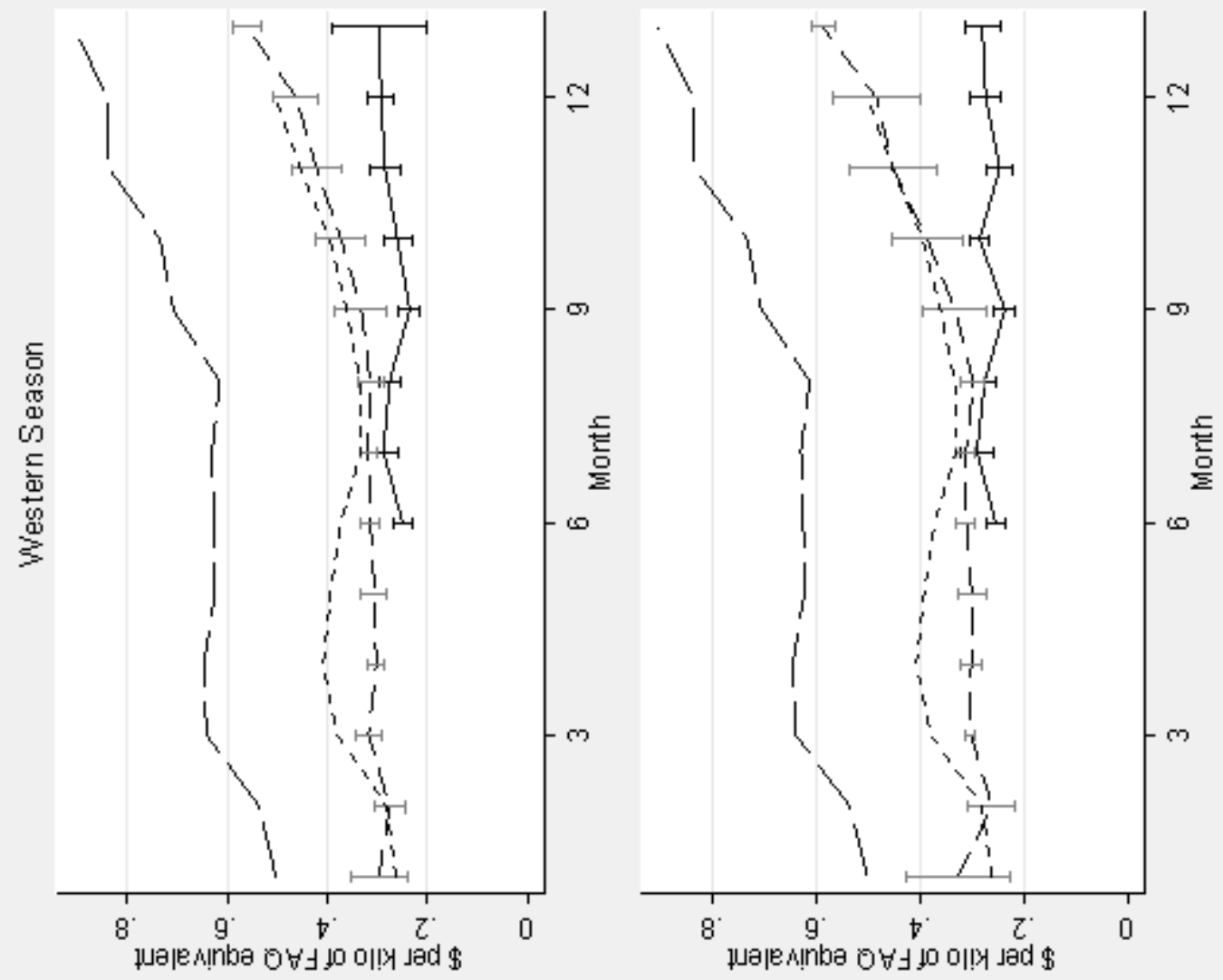

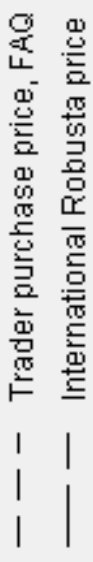

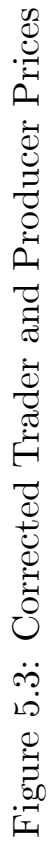
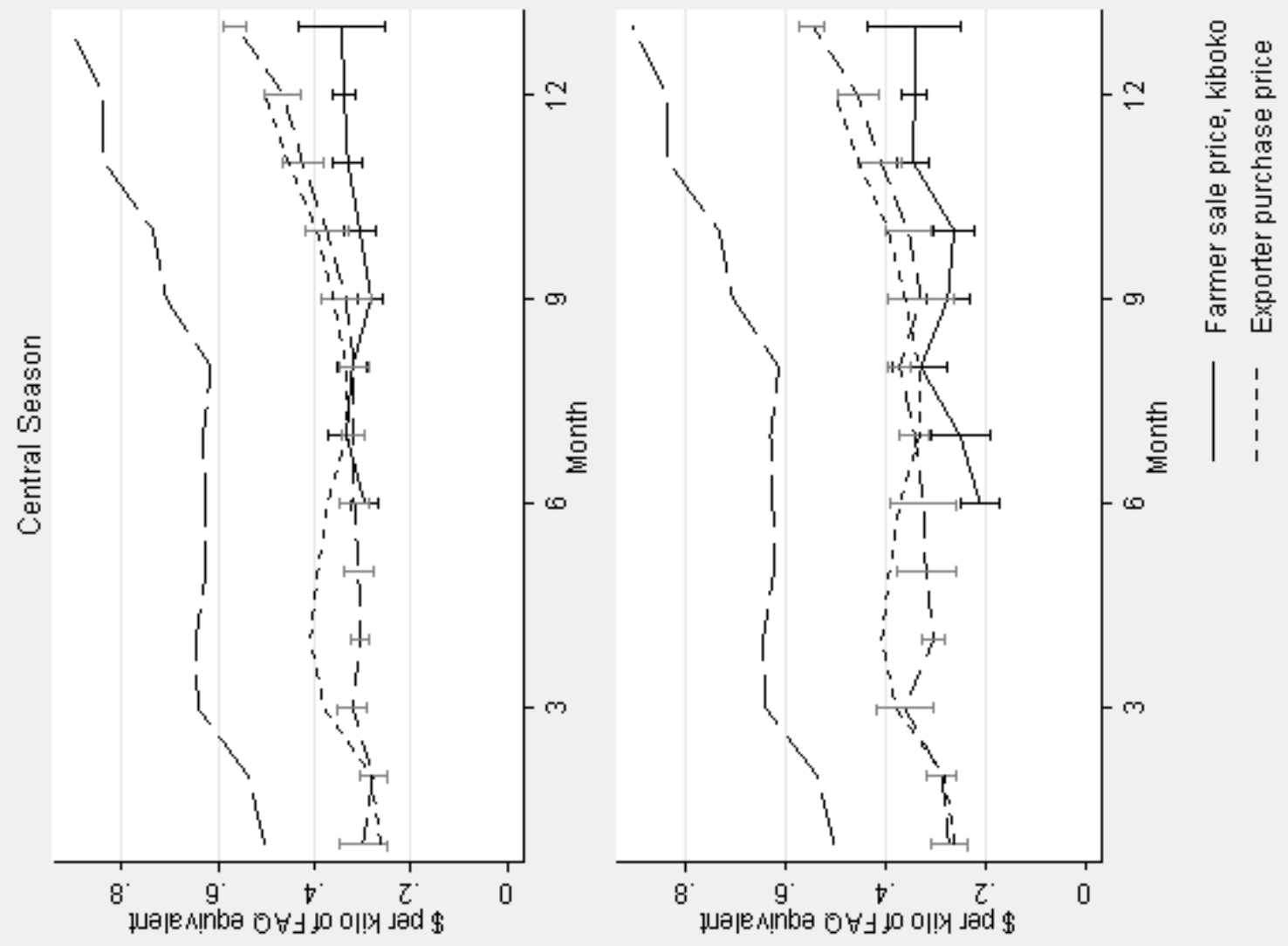


\subsection{Transaction costs}

In the conceptual section we have proposed two possible explanations why producer prices may increase less than proportionally with export prices. One possibility is that unit marketing costs increase with prices, either because they are proportional to value or because the increase in coffee supply raises the price of marketing services (transportation, handling, etc). The second possibility is that the export price increases triggers entry, thereby increasing search costs. We discuss these two possibilities in turn.

Let us first consider transactions costs. In the conceptual section we have argued that proportional market costs can exist in two ways: either if value-based marketing costs - such as working capital and storage costs - represent the bulk of transactions costs, or if increased coffee supply leads to a rise in the demand and price of marketing services.

We begin by noting that, in Uganda, aggregate coffee supply responds very little if at all to monthly fluctuations in price. Aggregating over surveyed FAQ and kiboko traders, we compute the total quantity of coffee purchased in each month of 2002. We then regress this quantity on price and a high season dummy separately for FAQ and kiboko and for the two regions covered by the survey. The estimated producer sale price comes from Figure 5.3. Regression results shown in Table (5.4) demonstrate that the harvest season dummy is highly significant but the average producer price has no significant effect on the aggregate quantity of coffee purchased. This not altogether surprising given that it takes three to five years for a new coffee tree to start bearing fruits: within the season, farmers have little flexibility in how much coffee they can harvest. Based on these results, it is extremely unlikely that transactions costs would rise due to increased demand for transportation and handling services. This leaves us with the possibility that transactions costs are value-based. We now turn to this possibility.

Survey results detail the kind of transactions costs incurred by Ugandan coffee traders. Table 


\begin{tabular}{lcccc}
\hline \hline & \multicolumn{2}{c}{ Central region } & \multicolumn{2}{c}{ Western region } \\
& FAQ traders & Kiboko traders & FAQ traders & Kiboko traders \\
\hline Estimated producer price & $1595.1(2145.1)$ & $112.14(221.60)$ & $-1663.9(2610.3)$ & $103.76(415.07)$ \\
High season dummy & $354.48(238.62)$ & $57.99\left(24.65^{* *}\right)$ & $1104.9\left(214.16^{* * *}\right)$ & $138.62\left(34.05^{* * *}\right)$ \\
Constant & $-38.34(577.84)$ & $-20.55(59.69)$ & $921.31(680.27)$ & $27.30(108.17)$ \\
\hline No. of observations & 12 & 12 & 12 & 12 \\
R-squared & 0.2656 & 0.4396 & 0.7006 & 0.6102 \\
\hline \hline
\end{tabular}

Table 5.4: Effect of price and season on total quantity purchased, dependent variable is total quantity purchase in tonnes by traders of a given type in a given region (standard errors in parenthesis, ${ }^{* *}$ significant at $0.99,{ }^{* *}$ significant at $0.95,{ }^{*}$ significant at $0.90, '$ significant at $0.85)$

(5.5) describes the transaction costs faced at each of the three points of the marketing chain.

Based on our a priori understanding of the nature of marketing costs, we divide them into costs that are expected to vary with quantity - such as bagging, transportation, milling and sorting and costs that can be expected to vary with value, such as working capital, agent commissions, and insurance. We also report costs - such as personal transport - that are not expected to vary with either quantity or value.

The Table shows that, at all stages of the marketing chain, most transaction costs increase with quantity, not with value. This is particularly true for traders who buy directly from farmers. For these traders, on average $78 \%$ of transactions costs comes from bagging and sewing, transport and milling costs. Transport, processing and bagging are also the largest transaction costs faced by exporters and FAQ traders. ${ }^{25}$

Ugandan coffee traders hold virtually no stocks and rotate their working capital extremely rapidly. The survey indeed shows that, for the most recent completed coffee transaction, the median length of time elapsed between purchase and sale to an exporter is 2 days. Furthermore $88 \%$ of surveyed traders report that, in their latest completed coffee transaction, at most a week elapsed between purchase and sale. ${ }^{26}$ It therefore comes as no surprise that, on average,

\footnotetext{
${ }^{25}$ The bags used by exporters for shipping coffee are expensive: bagging accounts for about $25 \%$ of variable exporter costs.

${ }^{26}$ The data also show that most traders do not operate on contract with exporters, and that those who do have
} 


\begin{tabular}{|c|c|c|c|}
\hline & $\begin{array}{c}\text { Exporter } \\
\text { (median in US\$) }\end{array}$ & $\begin{array}{c}\text { FAQ traders } \\
(\text { median in US } \$)\end{array}$ & $\begin{array}{l}\text { Kiboko traders } \\
\text { (median in US\$) }\end{array}$ \\
\hline Total variable costs of transaction & 0.061 & 0.016 & 0.028 \\
\hline Costs that vary with quantity (share) & $0.044(77 \%)$ & $0.006(52 \%)$ & $0.020(78 \%)$ \\
\hline \multicolumn{4}{|c|}{ Median expenditure for traders who reported incurring the following costs: } \\
\hline bagging and sewing & 0.015 & 0.001 & 0.003 \\
\hline transport & 0.010 & 0.006 & 0.008 \\
\hline milling costs & 0.021 & - & 0.013 \\
\hline picking costs & 0.009 & - & - \\
\hline Costs that vary with value (share) & $0.008(13 \%)$ & $0.002(19 \%)$ & $0.0005(2 \%)$ \\
\hline \multicolumn{4}{|c|}{ Median expenditure for traders who reported incurring the following costs: } \\
\hline commission & 0.005 & 0.007 & 0.011 \\
\hline cost of working capital & 0.006 & 0.0004 & 0.0001 \\
\hline taxes & 0.007 & - & - \\
\hline insurance & 0.001 & - & - \\
\hline \multicolumn{4}{|l|}{ Other costs } \\
\hline \multicolumn{4}{|c|}{ Median expenditure for traders who reported incurring the following costs: } \\
\hline personal transport & 0.005 & 0.001 & 0.003 \\
\hline other costs & 0.005 & 0.003 & 0.004 \\
\hline
\end{tabular}

Table 5.5: median variable cost per kilo

financing costs account for only $0.01 \%$ of the total costs of a transaction and that only $2 \%$ of the costs of a transaction can be identified as varying with coffee value.

Table (5.5) makes it a priori unlikely that transactions costs increase with price because they are value-based. It is however conceivable that actual transactions costs increase with price for reasons we do not understand. To investigate this possibility, we examine transactions costs per Kg reported by different traders for the last transaction they made and we test whether these unit costs vary systematically with the price at which they purchased the coffee. We control for quantity, the distance the coffee was transported, the time elapsed between purchase and sale, and whether the coffee was milled by the trader. Results are shown in Table (5.6) for all traders together, and for FAQ and kiboko traders separately. We find no significant increase in unit costs for transactions with higher coffee prices. From this convergence of evidence, we conclude that an increase in marketing costs is extremely unlikely to explain why producer prices increase very short delivery contracts of 7 days or less. 


\begin{tabular}{lccc}
\hline \hline & All traders & FAQ traders & Kiboko traders \\
\hline Purchase price (US cents per kilo of FAQ equivalent) & -0.021 & -0.029 & -0.021 \\
& $(0.017)$ & $(0.025)$ & $(0.027)$ \\
Quantity purchased (tons of FAQ equivalent) & -0.006 & -0.001 & -0.128 \\
& $(0.013)$ & $(0.012)$ & $\left(0.070^{*}\right)$ \\
Dummy if coffee was milled by trader (1 = milled) & 1.380 & - & 1.707 \\
& $\left(0.310^{* * *}\right)$ & - & $\left(0.835^{* *}\right)$ \\
Distance coffee transported (miles) & 0.006 & 0.007 & 0.011 \\
& $(0.004)$ & $\left(0.004^{\prime}\right)$ & $(0.012)$ \\
Duration of contract (days) & 0.027 & 0.033 & 0.016 \\
& $(0.026)$ & $(0.027)$ & $(0.052)$ \\
Constant & 0.027 & 0.029 & 0.025 \\
& $\left(0.009^{* * *}\right)$ & $\left(0.013^{* *}\right)$ & $\left(0.012^{* *}\right)$ \\
\hline Number of observations & 101 & 41 & 60 \\
R-squared & 0.2249 & 0.0541 & 0.0306 \\
\hline \hline
\end{tabular}

Table 5.6: Effect of price and quantity on transaction costs, dependent variable is total per kilo transaction costs in US cents standard errors in parenthesis, ${ }^{* * *}$ significant at $0.99,{ }^{* *}$ significant at $0.95,{ }^{*}$ significant at 0.90, ' significant at 0.85

less than proportionally with export prices.

\subsection{Information asymmetries and trader entry}

We now turn to our second possible explanation for the lack of responsiveness of producer prices, namely entry and exit of traders - particularly ddebe boys. As we discussed in the conceptual section, this is made possible by farmers' ignorance of movements in international prices. The literature on agricultural markets in Africa indeed suggests that, whilst traders are very knowledgeable about prices in their purchase and sale markets, farmers are much less knowledgeable about price movements (e.g. Coulter \& Golob 1992, Jones 1995, Coulter \& Onumah 2002). Traders may be able to take advantage of farmers' ignorance by increasing their trade margin when the price increases. This in turn may attract trader entry, leading to negative search externalities. Increased trader entry may also increase the number of hands through which coffee passes in the value chain, a possibility that we have not formally modeled but that follows an argument similar to that of trader entry. 


\begin{tabular}{lccc}
\hline \hline $\begin{array}{l}\text { Date at which } \\
\text { business started }\end{array}$ & $\begin{array}{c}\text { FAQ } \\
\text { traders }(\%)\end{array}$ & $\begin{array}{c}\text { Kiboko } \\
\text { traders }(\%)\end{array}$ & $\begin{array}{c}\text { Average international } \\
\text { Robusta price (1991 US\$) }\end{array}$ \\
\hline Pre- liberalization (1991) & 30.23 & 13.56 & \\
$1991-1993$ & 4.66 & 16.95 & $\$ 1.03$ \\
$1994-1996$ & 37.20 & 33.89 & $\$ 2.17$ \\
$1997-1999$ & 23.26 & 20.33 & $\$ 1.42$ \\
$2000-2002$ & 4.66 & 15.24 & $\$ 0.58$ \\
\hline \hline
\end{tabular}

Table 5.7: Entry of traders into business

We would like to know whether these phenomena are present in Uganda coffee markets. The data limit the extent to which we can test the hypothesis that traders enter when the price is high. Indeed, the data were collected from traders listed and sampled at only one point - when the price was high. However from the information that was collected, two things can be noted that concur with the hypothesis suggested.

First, as shown in Table (5.7), many of the coffee traders interviewed in our survey started trading coffee at a time when international coffee prices were high - between 1994 and 1996 . Very few traders have entered the market in the last few years when international coffee prices have been much lower.

Secondly, agricultural traders in sub-Saharan Africa do not specialize in a single crop and typically trade many agricultural products. Trader entry and exit can also be studied by examining when traders actively traded coffee in the 12 months preceding the survey. We want to test whether more traders are actively trading coffee when the average price is higher. To this effect, we estimate a logit model in which the dependent variable $y_{i t}$ equals 1 if a trader $i$ is active in month $t$, and zero otherwise. Because trading activity is higher during the harvest season, we include a harvest season dummy. Unobserved heterogeneity is controlled for via trader fixed effects. Results, shown in Table (5.8), conform to our expectations: a rise in the FAQ price at which small traders sell their coffee induces entry.

To verify that this process effectively increases the total number of traders, we also regress 


\begin{tabular}{lc}
\hline \hline & All traders \\
\hline Estimated FAQ purchase price $\left(\widehat{P}_{F A Q}\right.$ from Fig 5.3$)$ & $12.83\left(1.43^{* * *}\right)$ \\
High season dummy & $2.55\left(0.17^{* * *}\right)$ \\
\hline No. of observations & 1152 \\
Log likelihood & -381.11 \\
LR $\chi^{2}$ & $355.05^{* * *}$ \\
\hline \hline
\end{tabular}

Table 5.8: Conditional fixed effects logistic regression on whether or not a trader is active in a given month (standard errors in parenthesis, $* * *$ significant at 0.99 )

the proportion of traders buying and selling coffee in each month on the price of coffee in that month. A harvest dummy is included as well. Separate regressions are estimated for FAQ and kiboko traders. As discussed earlier, the harvest season is different in the Central and Western regions, so we estimate the regression separately for each region. Because the number of usable observations is quite small, we also estimate a pooled regression in which coefficients are allowed to vary across categories.

The results, shown in Table (5.9), provide unambiguous evidence that, in any given month, the number of traders actively buying and selling coffee varies strongly with price. The results are perhaps most convincing in the Western region because, in that region, the harvest season - which is a period of high coffee buying activity - happened to coincide with a period of low international coffee prices. Regression results indicate that, in that region, the number of active FAQ traders did not vary significantly with the price, but the number of traders buying directly from farmers - the kiboko traders - did. We also see that, in both regions the effect of price on the number of active traders is larger for kiboko. These results are consistent with the idea that high coffee prices incite traders to enter the market in order to take advantage of farmers' ignorance about the price increase.

In the modeling section, we argued that trader entry complicates search. From Table (5.4) we know that a rise in the coffee price has no significant effect on the aggregate quantity of coffee traded. It follows that, when the price rises, there are more traders chasing the same total 


\begin{tabular}{|c|c|c|c|c|c|}
\hline & \multicolumn{2}{|c|}{ Central region } & \multicolumn{2}{|c|}{ Western region } & \multirow[t]{2}{*}{ Pooled } \\
\hline & FAQ & Kiboko & FAQ & Kiboko & \\
\hline$\widehat{P}_{F A Q}$ from Fig 5.3 & $\begin{array}{c}82.17 \\
\left(18.37^{* * *}\right)\end{array}$ & $\begin{array}{c}91.95 \\
\left(26.07^{* * *}\right)\end{array}$ & $\begin{array}{c}9.36 \\
(7.74)\end{array}$ & $\begin{array}{c}54.98 \\
\left(14.06^{* * *}\right)\end{array}$ & \\
\hline $\begin{array}{c}\widehat{P}_{F A Q} * \text { dummy for Kiboko trader } \\
\text { in central region }\end{array}$ & & & & & $\begin{array}{c}102.13 \\
\left(15.25^{* * *}\right)\end{array}$ \\
\hline $\begin{array}{c}\widehat{P}_{F A Q}{ }^{*} \text { dummy for FAQ trader } \\
\text { in central region }\end{array}$ & & & & & $\begin{array}{c}76.55 \\
\left(15.25^{* * *}\right)\end{array}$ \\
\hline $\begin{array}{c}\widehat{P}_{F A Q} * \text { dummy for Kiboko trader } \\
\text { in western region }\end{array}$ & & & & & $\begin{array}{c}53.28 \\
\left(12.99^{* * *}\right)\end{array}$ \\
\hline $\begin{array}{c}\widehat{P}_{F A Q} * \text { dummy for FAQ trader } \\
\text { in western region }\end{array}$ & & & & & $\begin{array}{l}18.24 \\
(12.99)\end{array}$ \\
\hline High season dummy & $\begin{array}{c}8.05 \\
\left(1.84^{* * *}\right)\end{array}$ & $\begin{array}{c}15.14 \\
\left(2.61^{* * *}\right)\end{array}$ & $\begin{array}{c}5.48 \\
\left(1.01^{* * *}\right)\end{array}$ & $\begin{array}{c}12.92 \\
\left(1.84^{* * *}\right)\end{array}$ & \\
\hline High season ${ }^{*}$ Kiboko trader & & & & & $\begin{array}{c}13.89 \\
\left(1.33^{* * *}\right)\end{array}$ \\
\hline High season $*$ FAQ trader & & & & & $\begin{array}{c}7.04 \\
\left(1.33^{* * *}\right)\end{array}$ \\
\hline Western region dummy & & & & & $\begin{array}{c}19.20 \\
\left(6.07^{* * *}\right)\end{array}$ \\
\hline FAQ trader dummy & & & & & $\begin{array}{c}12.36 \\
\left(5.82^{* *}\right)\end{array}$ \\
\hline Constant & $\begin{array}{l}-19.44 \\
\left(6.53^{* *}\right)\end{array}$ & $\begin{array}{l}-26.14 \\
\left(9.26^{* *}\right)\end{array}$ & $\begin{array}{c}6.08 \\
\left(2.95^{*}\right)\end{array}$ & $\begin{array}{l}-10.37 \\
\left(5.36^{*}\right)\end{array}$ & $\begin{array}{c}-29.32 \\
\left(5.49^{* * *}\right)\end{array}$ \\
\hline No. of observations & 12 & 12 & 12 & 12 & 48 \\
\hline R-squared & 0.8104 & 0.8321 & 0.7189 & 0.8182 & 0.8149 \\
\hline
\end{tabular}

Table 5.9: Effect of price and season on number of traders active in the market, dependent variable is number of traders of a given type active per month in a given region (standard errors in parenthesis, ${ }^{* * *}$ significant at $0.99,{ }^{* *}$ significant at $0.95,{ }^{*}$ significant at 0.90$)$ 
quantity of coffee.

How this is reflected in the prices paid and quantities purchased by traders depends on whether traders are undifferentiated - the first version of our model of trader entry - or differentiated - the second version with entry at the ddebe boys level only. In the undifferentiated case, all traders purchase from producers. A rise in $p_{x}$ triggers entry and reduces quantity purchased for all traders while keeping the purchase price constant. In the differentiated case, traders who specialize in search are those who enter and exit; those who specialize in assembly are permanent. Prices paid by permanent traders are higher and rise with $p_{x}$ while prices paid by occasional traders are lower, reflecting the cost of search. Furthermore, quantities purchased by permanent traders remain constant.

To investigate which model best fits the data, we look at how purchase prices and quantities vary with $p_{x}$. We begin by looking at quantity purchased and estimate a regression in which the dependent variable is the quantity of coffee $Q_{i t}$ purchased by trader $i$ in month $t$ and the regressor is the median price paid in month $t$ by all traders operating in the same district as i. A harvest season dummy is included to control for possible changes in aggregate supply. We also include trader fixed effects to control for unobserved heterogeneity. Two regressions are estimated. The first one includes all traders operating in month $t$. Since many traders only operate during part of the year, this regression only includes those traders in the months during which they are actively trading coffee: when they are not trading coffee, presumably they do not raise search costs for others. We also estimate a regression limited to permanent traders, that is, those who are active throughout the year. In the first model, they should bear the brunt of reduced sales; in the second model, they should see no change in total quantity purchased.

Results are shown in Table (5.10). As predicted by the first model, the price coefficient is negative and it is more negative for traders active throughout the year. But the effect is not 


\begin{tabular}{lcc}
\hline \hline$Q_{\text {it }}$ & All traders, conditional on trading & Traders active throughout year \\
\hline Median price paid in district & $-10.12(33.84)$ & $-109.90(115.53)$ \\
High season dummy & $24.22\left(3.59^{* * *}\right)$ & $45.23\left(10.07^{* * *}\right)$ \\
Constant & $20.00\left(11.24^{*}\right)$ & $77.31\left(36.78^{* *}\right)$ \\
\hline No. of observations & 632 & 175 \\
R-squared & 0.0043 & 0.0693 \\
No. of groups & 102 & 16 \\
F-test that all fixed effects $=0$ & $F(101,528)=8.84^{* * *}$ & $F(15,157)=8.59^{* * *}$ \\
Fraction of variance due to f.e. & 0.529 & 0.432 \\
\hline \hline
\end{tabular}

Table 5.10: Effect of price and season on the quantity purchased by trader i at time $\mathrm{t}$ (standard errors in parenthesis, $* * *$ significant at $0.99,{ }^{* *}$ significant at $0.95,{ }^{*}$ significant at 0.90, significant at 0.85 )

statistically significant. We also note that, as predicted by the second model, permanent and occasional traders are quite different in the size of their operation in the sense that entering traders are very small. To illustrate this, we compare the median traded quantity of traders operating throughout the year with that of traders who are active part of the year. As expected, the median monthly purchase for continuously trading individuals is $43200 \mathrm{Kg}$. of FAQ equivalent coffee, while it is only $5000 \mathrm{Kg}$. for occasional coffee traders.

Next we examine the effect of a rise in the export price on prices paid by kiboko traders. In the undifferentiated model with complete farmer inertia, we expect prices paid by traders to remain constant. In contrast, in the differentiated model, the average price paid by surveyed traders is a mix of two effects: a constant price paid to farmers and an increasing $p_{x}-a$ price paid by permanent traders. Table (5.2) has already shown that the average price paid by kiboko traders increases with the FAQ price, albeit at a slower rate - a result consistent with the differentiated model.

We also investigate whether occasional traders pay a price that is significant lower than that paid by permanent traders. In our first model of trader entry, traders are undifferentiated so that on average they all purchase at the same price. In our second model, occasional traders purchase directly from farmers while permanent traders may purchase from occasional traders. 


\begin{tabular}{lccc}
\hline \hline & All traders & Traders in central region & Traders in western region \\
\hline January 2002 & $0.294(0.031)$ & $0.296(0.045)$ & $0.313(0.024)$ \\
February & $0.289(0.021)$ & $0.326(0.046)$ & $0.293(0.001)$ \\
March & $0.287(0.023)$ & $0.230(0.023)$ & $0.318(0.015)$ \\
April & $0.244(0.020)$ & $0.329(0.032)$ & $0.255(0.004)$ \\
May & $0.298(0.042)$ & $0.306(0.014)$ & $0.319(0.040)$ \\
June & $0.250(0.023)$ & $0.302(0.022)$ & $0.271(0.016)$ \\
July & $0.263(0.020)$ & $0.273(0.030)$ & $0.284(0.011)$ \\
August & $0.279(0.020)$ & $0.262(0.043)$ & $0.301(0.010)$ \\
September & $0.304(0.024)$ & $0.250(0.022)$ & $0.345(0.021)$ \\
October & $0.329(0.027)$ & $0.291(0.017)$ & $0.376(0.037)$ \\
November & $0.389(0.029)$ & $0.361(0.013)$ & $0.446(0.051)$ \\
December & $0.416(0.018)$ & $0.436(0.008)$ & $0.405(0.053)$ \\
January 2003 & $0.460(0.019)$ & $0.498(0.014)$ & $0.447(0.030)$ \\
Occasional trader dummy & $-0.037\left(0.016^{* *}\right)$ & $-0.033\left(0.015^{* *}\right)$ & $-0.050\left(0.029^{*}\right)$ \\
Western region dummy & $0.021(0.018)$ & & 198 \\
\hline No. of observations & 389 & 191 & 0.4191 \\
R-squared & 0.4435 & 0.5962 & \\
\hline \hline
\end{tabular}

Table 5.11: Results from regression on kiboko trader purchasing prices (All month dummies are significant at 0.99$)$

As a result, the price paid by occasional traders should, on average, be lower. To investigate this, we regress the price paid by traders for kiboko (unmilled) coffee on monthly dummies and an occasional trader dummy. If the second model applies, this dummy should be significant. Results are presented in Table (5.11) for the pooled sample and separately for the Central and Western regions. Occasional traders are defined as those trading coffee for 3 months or less. All monthly dummies are significant at the $1 \%$ level. We see that the occasional trader dummy is strongly significant in all three regressions, providing additional support for the second model.

Taken together, the weight of the evidence favors the trader entry explanation. It appears that a rise in the international coffee price induces small occasional traders to enter coffee trade in order to capture part of the price increase from ignorant producers. They do so by inserting themselves between producers and established traders. Ironically, this perverse outcome is achieved in spite of considerable competition between traders. 


\section{Conclusion}

We have examined the transmission of international coffee prices to Ugandan Robusta growers. Most of what we know about the transmission of prices to small African growers comes from data collected at the market level (e.g. Dercon 1995, Shively 1996, Badiane \& Shively 1998, Fafchamps \& Gavian 1996). This paper innovates by combining price information collected in three simultaneous surveys covering all levels of the value chain in Uganda.

As in previous studies, we find that fluctuations in the international coffee price are reflected relatively rapidly in domestic prices paid by exporters and large traders. However fluctuations in the international price are not fully reflected in the farm-gate price. In particular, the volatility of the farm-gate price is not found to be as high as a model of constant transaction costs and perfect or monopsonistic competition would suggest.

To account for this finding, we examine two possible explanations: transactions costs and trader entry. We first check whether transactions costs increase with price. We find that they do not. We then investigate whether the number of traders rises when the price increases. We find that it does, a situation that may arise from farmers' ignorance of coffee price movements

We then seek to distinguish between two versions of the trader entry explanation. If traders are undifferentiated, a rise in price should be associated with a constant purchase price and a fall in quantity traded. In contrast, if traders have different relative factor costs, traders with more working capital should specialize in assembly while traders with a lower opportunity cost of time specialize in search. Assembly traders should be more permanent and on average pay a higher price than search traders whose number fluctuates. We do not find significant evidence that quantity traded falls with the export price, as would be the case if traders were undifferentiated, but we find evidence of entry by small traders when the international price rises.

Taken together, our results suggest that an increase in the export price attracts small itin- 
erant traders to coffee trading. By touring the countryside in search of coffee, these occasional traders take advantage of farmer's ignorance about movements in international prices to insert themselves between producers and large traders. To our knowledge, this is the first time that such perverse process is rigorously documented.

The data that we collected unfortunately do not enable us to check how long it takes for

farmers to realize that the export price has risen. It is also unclear whether disseminating information about the coffee export price would help eliminate the parasitic role of occasional traders. These issues deserve further enquiry.

\section{References}

Akiyama, Takamasa, Donald Larson, Panos Varangis \& John Baffes. 1999. "Market Liberalization: Lessons Across Country and Commodity Experiences." (mimeograph).

APSEC. 1999. Report on Economics of Crops and Livestock Production, Processing and Marketing 1998-99. Kampala, Uganda: Agricultural Policy Committee of the Agricultural Policy Secretariat (APSEC).

Badiane, Ousmane \& Gerald E. Shively. 1998. "Spatial Integration, Transport Costs, and the Response of Local Prices to Policy Changes in Ghana." Journal of Development Economics $56(2): 411-31$.

Baulch, Bob. 1997. "Transfer Costs, Spatial Arbitrage, and Testing for Food Market Integration." American Journal of Agricultural Economics 79(2):477-487.

Beynon, Jonathan, Stephen Jones \& Shujie Yao. 1992. "Market Reform and Private Trade in Eastern and Southern Africa." Food Policy 17(6):399-408. 
Coulter, J. \& C. Poulton. 1999. Cereal Market Liberalization in Africa. In Commodity Reforms: Background, Process, and Ramifications. Washington D.C.: The World Bank.

Coulter, Jonathan \& G. Onumah. 2002. "The Role of Warehouse Receipt Systems in Enhanced Commodity Marketing and Rural Livelihoods in Africa." Food policy 27(4):319-37.

Coulter, Jonathan \& Peter Golob. 1992. "Cereal Marketing Liberalization in Tanzania." Food Policy 17(6):420-30.

Deaton, Angus \& Ron Miller. 1996. "International Commodity Prices, Macroeconomic Performance, and Politics in Sub-Saharan Africa." Journal of African Economies 5(3):99-191. Supplement Part I.

Dercon, Stefan. 1995. "On Market Integration and Liberalisation: Method and Application to Ethiopia." Journal of Development Studies 32(1):112-143.

Fafchamps, Marcel \& Bart Minten. 1999. "Relationships and Traders in Madagascar." Journal of Development Studies 35(6):1-35.

Fafchamps, Marcel, Eleni Gabre-Madhin \& Bart Minten. 2005. "Increasing Returns and Market Efficiency in Agricultural Trade." Journal of Development Economics . (forthcoming).

Fafchamps, Marcel \& Ruth Vargas Hill. 2005. "Selling at the Farm-Gate or Travelling to Market." American Journal of Agricultural Economics 87(3):717-34.

Fafchamps, Marcel \& Sarah Gavian. 1996. "The Spatial Integration of Livestock Markets in Niger." Journal of African Economies 5(3):366-405.

Gardner, Bruce. 1975. "The Farm Retail Price Spread in a Competitive Industry." Americal Journal of Agricultural Economics 57:399-409. 
Gilbert, Christopher L. 1993. Domestic Price Stabilization Schemes for Developing Countries. In Managing Commodity Price Risk in Developing Countries. Baltimore and London: Stijn Claessens (ed.), John Hopkins University Press for the World Bank pp. 30-67.

Henstridge, N.M. 1997. The Reconstruction of a Macroeconomic Dataset for Uganda. Technical Report 98-3 Centre for the Study of African Economies Working Paper Series.

Hill, Ruth Vargas. 2005. "Risk, Production and Poverty: A Study of Coffee in Uganda." (unpublished PhD thesis).

Jones, Stephen. 1995. "Food Market Reform: The Changing Role of the State." Food Policy 20(6):551-60.

Kawuma, Frederick S.M. \& John N. Byarugaba. 1996. "Prognosis of the Coffee Trade in Uganda: A Review of Liberalisation and its Impact on the Coffee Trader in Uganda and the Role of the Uganda Coffee Trade Federation." (mimeograph).

Kempaka, Gloria. 2001. Coffee and its impact and relevance to PEAP (Poverty Eradication Action Plan). In The Coffee Yearbook. Kampala, Uganda: Envoys Promotion Consultants for Uganda Coffee Trade Federation.

Newbery, David \& Joseph Stiglitz. 1981. The Theory of Commodity Price Stabilization: A Study in the Economics of Risk. Oxford UP.

Nsibirwa, Robert Waggwa. 1999. Analysis of Trends of Coffee Trade Structures in Uganda. In The Coffee Yearbook 1998-1999. Kampala, Uganda: Uganda Coffee Trade Federation, Envoys Promotion Consultants.

Nsibirwa, Robert Waggwa. 2001. "Emerging Concentration in the Coffee Exports Sector in Uganda." (unpublished MA thesis). 
Ponte, Stefano. 2001. Coffee Markets in East Africa: Local Responses to Global Challenges or Global Responses to Local Challenges? Technical Report 01.5 Cenre for Development Research Working Paper Copenhagen: .

Shepherd, Andrew \& Stefano Farolfi. 1999. Export Crop Liberalisation in Africa: A Review. Vol. 135 Rome: FAO Agricultural Services Bulletin.

Shively, Gerald E. 1996. "Food Price Variability and Economic Reform: An ARCH Approach for Ghana." American Journal of Agricultural Economics 78(1):126-136.

Staatz, John M., Josue Dione \& N. Nango Dembele. 1989. "Cereals Market Liberalization in Mali." World Development 17, no.5:703-718.

The Bank of Uganda. 2001. Annual Report 2000-2001. Kampala, Uganda: Bank of Uganda.

Uganda Coffee Trade Federation. 2001. The Coffee Yearbook 2000-2001. Kampala, Uganda: Uganda Coffee Trade Federation, Envoys Promotion Consultants. 